\title{
Auckland: rescaled governance and post-suburban politics
}

\author{
Jenny McArthur ${ }^{\mathrm{a}}$ \\ ${ }^{a}$ Department of Science, Technology, Engineering 8 Public Policy \\ University College London \\ Boston House, 36-38 Fitzroy Square, London W1T 6EY
}

\begin{abstract}
The nature and politics of urban development in Auckland have undergone rapid transformation following amalgamation of eight separate authorities in 2010. Institutions governing metropolitan planning and infrastructure provision were rescaled to form the Auckland Super City Council in 2010, with an ambitious vision to become the world's most liveable city and ongoing political contestation between the local and central government. Amalgamation of Auckland's governance was conceived and imposed by the central government as part of a broader economic strategy centred on "competitive cities". However, Auckland Council's first strategic plan adopted a contrasting agenda, centred around the goal of "liveability". Auckland's recent developments illustrate the challenges of a distinctly post-suburban polity. The majority of employment is located in suburban areas and the city has variegated and overlapping patterns in spatial form generated through inconsistent infrastructure interventions across local and national authorities. Conflicting urban policy agenda at national and local scales shows a tension between the pursuit of economic development and provision for collective needs. The politics of post-suburban development create specific challenges for Auckland's governance. s Liveability and economic competitiveness are treated as complementary terms in political rhetoric, however trade-offs emerge at a smaller spatial scales. Public concern over housing affordability and risks to the financial stability of New Zealand's economy have led to central government intervention and renegotiation of authority between different tiers of government for land use and infrastructure provision. Auckland's position as New Zealand's largest city and economic centre frequently blurs the distinction between issues of local and national significance. Auckland's governance challenges are not unique, however the current tensions are exacerbated by its dominance in a small and geographically-isolated nation.
\end{abstract}

Keywords: Governance, Urban growth, Post-suburban politics, Auckland, New Zealand

Email address: jenny.mcarthur@ucl.ac.uk (Jenny McArthur) 


\section{Background}

Auckland has a population of 1.57 million across approximately $560 \mathrm{~km}^{2}$ (Statistics New Zealand, 2015b). The region's geography is unusual: Auckland is centred on an isthmus, punctuated by approximately fifty volcanic cones with

5 sheltered harbours to the east and west. $34 \%$ of New Zealand's population live in Auckland, and the city generates $35 \%$ of New Zealand's gross domestic product (Statistics New Zealand, 2015a b). Auckland's spatial form is relatively dispersed, with higher residential and employment density in the city centre, and lower-density residential and employment patterns extending from the city

10 fringe to the urban periphery. Auckland has expanded far beyond the isthmus to the north and south, engulfing a number of historically-separate settlements.

Across Auckland's history, the region has experienced ongoing economic and social transformation. Auckland (formerly known as Tāmaki-makau-rau) was historically a productive agricultural area, with access to two harbours and fer-

15 tile soil due to the region's volcanic activity. In 1740 the indigenous Māori population was approximately 10,000, however tribal conflict meant that by 1826 there was no remaining residential settlement on the isthmus (Pownall, 2008). Following the arrival of European colonists, the city was selected as the capital of the New Zealand colony in 1841 (Bloomfield, 1967). Auckland's geographical

20 advantage made it a favourable location for settlement during the early years of colonisation. New Zealand had limited inland transport infrastructure and sea transport was essential for trade between regions. Auckland grew quickly, as it was well-equipped to support trade with protected harbours on both coastlines and also served as the country's administrative centre. Despite the transfer of

25 the capital city to Wellington in 1865, Auckland's population increased further to 12,500 by 1864 , and 58,000 by 1881 (Bloomfield, 1973). By 2015 Auckland's population of 1.57 million dwarfed New Zealand's next largest city of Christchurch, with only 370,000 residents. Auckland's growth took place under fragmented governance and different jurisdictions competed aggressively to 30 assert dominance over regional planning decisions and fundraising capabilities (Bush, 1990).

As a former British colony, New Zealand's population growth and changing ethnic composition has been heavily shaped by migration over the past 180 years. Immigration reform in the late 1980s led to even greater ethnic diver-

35 sity, particularly in urban centres. Fig. 1 shows the components of population growth in Auckland between 19972015. Significant, but volatile, international in-migration contrasts with net domestic out-migration, which has heavily influenced Auckland's ethnic composition. Forty percent of Auckland's current residents were born outside New Zealand, and the city is more diverse than 40 London and Los Angeles (Bruce, 2014).

Auckland's large variety of cultures include 213 different ethnic groups, and the largest urban population of indigenous Māori. Efforts by local institutions to support Auckland's diversity, including public celebrations around Matariki (Māori New Year), Chinese New Year and Diwali, have reinforced Auckland's 45 identity as a cultural melting pot that brings benefits for all residents (Johnson 


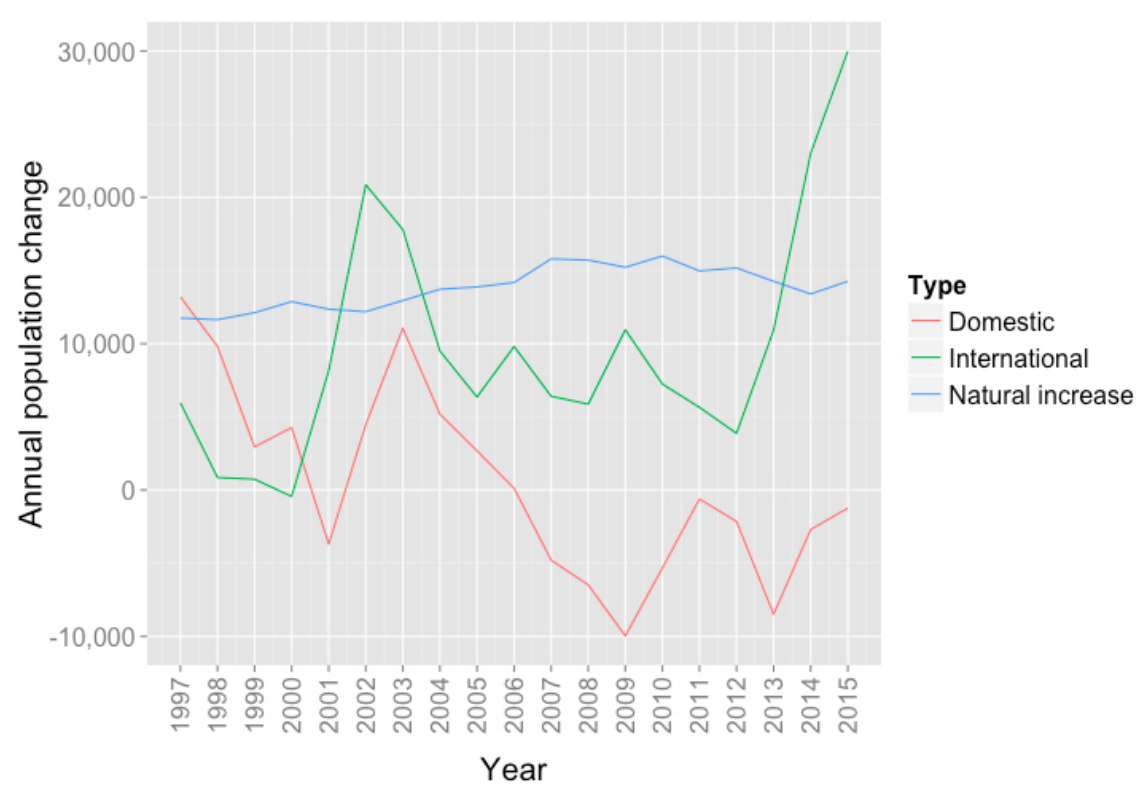

Figure 1: Components of population growth in Auckland (Statistics New Zealand 2015b)

\& Moloughney, 2007). Auckland's Māori heritage and population have particular significance for governance and planning. A large share of New Zealand's Māori population migrated to urban centres over the 20th century, accompanied by policies which undermined social structures and cultural practices (Barcham, so 1998). Currently, urban Māori experience poorer outcomes for education, housing quality, and health in New Zealand cities and urban governance faces a challenge to recognise the needs and heterogeneity across urban Māori populations (Gagné, 2016, Ryks et al., 2016).

\subsection{Urban governance in New Zealand}

55 The absence of an overarching urban policy in New Zealand has largely left urban issues to relevant sector-based policies around infrastructure provision, land use, and economic development (Zöllner, 2004). Over the 20th century local politics in Auckland were prone to dysfunction, pork-barreling and parochial interests (Bloomfield, 1973, Edgar, 2012). In the context of parochial-

${ }_{60}$ ism and political dysfunction, the preferred governance mechanism for much of the 20th century was the ad-hoc board: a specific-purpose entity to manage services or infrastructure facilities (Royal Commission on Auckland Governance, 2009). Given the demands of rapid growth, the efficiency of ad-hoc bodies to deliver infrastructure investments without requiring integrated planning or

65 consensus across neighbouring jurisdictions made them a popular short-term measure. Over the longer term this resulted in a proliferation of separate governing bodies: by 1960 the region had 31 territorial authorities and 16 ad hoc 
bodies, creating an extremely difficult environment for unified decision-making (Bush, 1972). Therefore Auckland's governance structure was driven by expedience, bowing under pressures to meet the immediate demands of growth rather than a unified long term vision. The governance and provision of region-wide infrastructure was repeatedly undermined by competition between jurisdictions. Major investments in water sources and reticulation systems, waste water treatment and transit provision were frequently contested and deferred (Harris, 2005.

75 La Roche, 2011). Often, political consensus was only reached after the deterioration of infrastructure led to a major failure or crisis (Fitzmaurice, 2009).

The multitude of governing authorities was streamlined by reforms imposed by the central government. The passing of the Auckland Regional Authority Act in 1963 led to Auckland's first region-wide authority, and further amalgamation

so of 22 local authorities to seven in 1990 further reduced the number of institutions governing Auckland (Bush, 1990). Ongoing renegotiation and hollowing out of the authority of Auckland's regional agencies demonstrates the difficulty in maintaining stable political relationships at the regional scale (Memon et al. 2007).

85 1.2. Rescaled governance: Auckland's Super City project

Following extended periods of political fragmentation and failed attempts to reform governance in 1906, 1927, and 1964 (Edgar, 2012, Bloomfield, 1967, 1973 Bush, 1972), four city councils, three district councils and one regional council were finally amalgamated to form a unitary authority in 2010.

Urban governance is a central instrument by which cities can re-orient themselves around global economic and political networks (Keil, 2000). Reconfiguration of governance reflects both the macro-economic logic or policies, and the actors and institutions which participate in local governance (Boudreau et al. 2006). Restructuring of urban governance through amalgamation negotiates

95 trade-offs between scale and efficiency, alongside imperatives for democratic representation and providing for the collective needs of urban populations. . Auckland's amalgamation was evidently a product of national economic strategy to strengthen urban economies. However, emerging tensions and the implementation of new governance mechanisms reflect the contingent assemblages of 100 actors participating in the city's governance, albeit with strong influence from the central government (Wetzstein, 2008).

Since 2000, the central government showed greater interest in Auckland's contribution to the national economy, as the region showed strong economic growth (Lewis \& Murphy, 2015). The central government's initiative for com105 petitive cities formed a key component of the economic agenda to support prosperity and future growth (Ministry for Local Government, 2009). Auckland was characterised as the engine room for New Zealand's economic growth (Ministry for Local Government, 2009). This shows the strategic role of Auckland for the central government, not primarily as a population centre, but a vehicle to

110 support the national economic strategy. Governance reforms were justified by imperatives for international competitiveness, Auckland's significance to the na- 
tional economy, and the desire to better serve interdependent needs for social, environmental, cultural and economic well-being (Salmon et al., 2009).

The conceptualisation of global cities as strategic units in their own right (World Bank, 2015) has influenced political discourse and expectations of how cities are organised, both economically and socially (Gupta et al. 2015; Sassen, 2005). While the geographic limits of Auckland's governance are bounded to $560 \mathrm{~km}^{2}$, the scale across which governance networks are influenced, and have subsequent impacts, is much broader. Success in global liveability rankings ${ }_{120}$ has influenced Auckland's policy goals, and Auckland's diversity results in a large number of international networks operating through and across the city. The prospect of amalgamation gained traction following an OECD delegation visit to New Zealand in 2006, and in 2007 a Royal Commission was set up by the Labour-led central government to re-examine Auckland's governance (?). In 125 March 2009 the Commission's final report was delivered to the new National-led government, recommending a two-tier structure with an overarching authority and local representation provided through sub-regional elected bodies. The acting government accepted most of the recommendations, with notable omissions around Auckland's representation at the central government level, Māori rep130 resentation on the governing body, and rejection of proposed second-tier local councils in place of community boards with limited responsibilities and fundraising capability. The amalgamation process was swift, managed by the Auckland Transition Agency between May 2009November 2010.

The amalgamated authority has fewer elected officials, in an effort to improve efficiency, however the relative scale of Auckland Council is substantial. With 8000 staff, annual revenues of NZ $\$ 2.9$ billion (US $\$ 2.1$ billion) and NZ $\$ 26$ billion (US $\$ 19$ billion) of assets, Auckland Council is currently the largest local government in the southern hemisphere (Chen, 2014: Thomas, 2014).

Auckland's new institutional arrangements for infrastructure delivery enable more co-ordinated, strategic planning of investments across the city. However the outcomes for democratic representation and public engagement are less certain. Voter turnout at local elections fell from $51 \%$ in 2010 to $35 \%$ in 2013 and recovered only slightly to $39 \%$ in 2016 , suggesting that public have limited engagement and understanding of the importance of elected officials in Auck-

145 land's development (Local Government New Zealand, 2016). An increasing democratic deficit in New Zealand is attributed to national reforms which shift power to the central government, eroding the legitimacy and integrity of local authorities (Cheyne, 2015). Under-representation of indigenous Māori in local governance in New Zealand is an ongoing challenge (Hayward, 2011). Political representation of Māori in Auckland takes the form of an independent board tasked with ensuring that Auckland Council comply with statutory provisions in the Treaty of Waitang: $\left.\right|^{1}$ and advising on issues that affect the Māori popu-

\footnotetext{
${ }^{1}$ The Treaty of Waitangi is New Zealand's founding document, which governs relations between indigenous Māori and non-Māori populations, and guarantees Māori rights and privileges.
} 
lation. The Royal Commission recommended three Māori council members on the governing body, however this was not adopted by the central government, and Māori representation remains limited (Gagné, 2016).

Rescaling of urban governance is characterised as the rescaling of state power in response to shifting economic dynamics, which increasingly concentrate at the scale of the city-region (Brenner, 2011). In Auckland's case, amalgamation initially appeared to strengthen the city politically by enabling scale and co-ordination for planning and public investments, and eliminating competition for funding between neighbouring jurisdictions. However, in political terms this has enabled the central government to intervene and influence Auckland to an extent which may not have been feasible when the city's governance was dispersed across eight different authorities. The incoherent politics of Auckland's post-amalgamation development reflect the in-between-ness of post-suburbia. Central government intervention and controls over the statutory powers of Auckland Council characterise state presence and state retreat from critical housing and transport issues, and conflicting interventions from local and central state actors (Young \& Keil, 2010; Murphy, 2016).

170 Auckland's governance challenges and distinctly post-suburban politics are explored in this profile. Rescaling of the city's governance has revealed the nature of post-suburbia through the politics of land development and ongoing contestation over authority, decision-making and accountability for large-scale infrastructure investments.

\section{Post-suburban politics of development}

The post-suburban polity emerges from the evolution of suburbs beyond their original function as solely residential areas serving commercial activity in the urban core. Post-suburbia has distinct regional variation, with disparities in the scale and nature of post-suburban forms between European, North American, and Chinese cities (Phelps, 2010, Wu \& Phelps, 2011). Auckland's suburbs have evolved to accommodate greater economic activity and varied land-use patterns shaped by transport infrastructure. While Auckland's early suburbs were supported by a network of tramways, the majority of current suburban areas developed after this network was removed in the 1950s. The mass production 185 of private automobiles, expansion of roading infrastructure and residential development of greenfield areas produced low-density residential areas extending into the city's hinterland (Modarres \& Kirby, 2010; Teaford, 2011). Auckland's suburbanisation led to a decline in the city centre. Despite a recent resurgence in population and employment in the city centre, suburban areas still retain an $84 \%$ share of employment (Statistics New Zealand, 2013). This brings a broader range of interests to urban politics, beyond the landed interests dominant in urban growth machine and urban regime theory. However following the emergence of a property market bubble in Auckland in 2013, land ownership is still an important driver of the politics of development. The increased complex 
urban economy and society (Young \& Keil, 2014). Conflicting infrastructure interventions from local and central government, and opposing forces of dispersion and centralisation, are reflected in Auckland's disjointed and sprawling spatial form.

Specific tensions in governing post-suburban areas arise as, several decades after initial suburban expansion, urban governance must address global environmental and economic risks. This is characteristic of the second modernity where critical societal issues emerge at the global scale (Beck, 1992). New urban policy goals aim to reduce green gas emissions, mitigating the risks of climate change, and cater for active transport modes challenge the dominant modes of development and mobility for suburban areas (Kennedy et al., 2005, Mitchell et al. 2015). Therefore challenges arise for cities with strong population growth and imperatives to change the way that land and infrastructure are used.

Auckland's spatial development and contestation over land use policy illustrate the politics of post-suburban growth. Governance mechanisms are central drivers of change that enable suburban spaces to be re-worked to adapt to changing demands and priorities for land use (Phelps, 2015, p.74). The rescaling of Auckland's governance impacts on the politics of growth in multiple ways. A 215 single governing body provided the platform for a new urban policy agenda, accompanied by specific tools to implement this agenda through spatial planning and infrastructure investment. Legislation introduced in 2010 to enable Auckland's amalgamation included provisions for a strategic spatial plan, and created new institutions to integrate delivery of infrastructure services. The strategic spatial plan, also known as the Auckland Plan, set out the city's goals for the next thirty years, and required transitions to achieve these. Attempts to implement strategic spatial planning in Auckland show the tensions of governing post-suburbia: contestation between the pursuit of economic growth and provision for collective consumption, conflict over how best to accommodate 225 growth while preserving the quality of the existing environment, and the resulting pressures on different levels of government to intervene (Phelps et al. 2010 .

\subsection{New urban agendas: competitive and liveable cities?}

Reform of Auckland's governance resulted from New Zealand's national agenda for international competitiveness. The central government led an initiative for competitive cities as a key component of the national economic agenda to support prosperity and future growth (Ministry for Local Government, 2009). However Auckland's amalgamation has subsequently enabled a new local agenda oriented toward liveability and broader social and economic goals.

235 International trends toward a new urban entrepreneurialism have influenced New Zealand's urban policy since the 1990s (Horton, 1995), treating cities as economic entities in themselves which can leverage their competitive advantage (Porter, 1995). The competitive cities strategy utilises land-use policy to foster spatial agglomeration and greater economic performance. In 2002 the Auck-

240 land Regional Economic Development Strategy was launched as an initiative of 
purported national significance, as Auckland's growth had strong potential to increase New Zealand's GDP earnings, as a way to build export markets and attract foreign investment (Tizard, 2002). Supporting the international competitiveness of New Zealand cities is now a primary component of the central government's economic agenda (Ministry for the Environment, 2010). This shift in urban policy attributed greater economic significance to the city as the preeminent spatial form to support quality of life and economic growth Ministry for the Environment, 2010). While the competitiveness agenda was led by the central government, Auckland's goal to become the world's most liveable city was introduced by the newly-amalgamated Auckland Council as the overarching vision for the Auckland Plan, released in 2012. Auckland's adoption of liveability as a policy goal shows how the concept can be appropriated as an international branding exercise, or alternatively used to shape a more inclusive and equitable urban policy. Ranking highly in the Economist Intelligence Unit's Global Liveability Ranking, Mercer's Quality of Living Survey, and Monocle magazine's Quality of Life Survey is perceived to attract foreign investment and skilled workers (Auckland Council, 2016b). However the measures adopted within global rankings take a narrow view on liveability, catering to the specific needs of high-income, highly skilled individuals with specific lifestyle preferences.

260 An approach to liveability that focuses solely on attracting skilled workers and foreign investment may come at the expense of improving local services and amenities for existing residents, and the specific needs of elderly, youth and disabled populations. Liveability is underpinned by the everyday experiences of people living in cities, and takes many different meanings to different people (Ley, 1990). The vision set out in the Auckland Plan adopts an inclusive definition of liveability, aiming to create a strong, inclusive and equitable society that ensures opportunity for all Aucklanders (Auckland Council, 2012). Realising this definition of liveability depends on the implementation of the Auckland Plan into infrastructure investment and spatial planning. While liveability 270 and competitiveness are often treated as compatible outcomes within political rhetoric, there are clear tensions between these goals in post-suburban cities. The pursuit of economic growth and required provisions for social and physical infrastructure are related at the regional level, however conflicts and disparities can arise at the scale of local communities (Cox \& Jonas, 1993; Phelps, 2015).

The introduction of the agenda for liveability and competitiveness show that the scope of what is governed at the local level has shifted profoundly. The traditional role of local government authorities has been described anecdotally as the proverbial three Rs: roads, rubbish and rates (Memon, 2008), reflecting a minimal level of responsibility for basic public services. This mandate is expanded to encompass wide-reaching economic, social and environmental outcomes with the agenda for liveability. It is questionable whether local government can effect change in wider economic, social and environmental outcomes without coordinated planning with other central government agencies (Memon et al., 2007). Given Auckland's pressing need to address the standard of housing and trans285 port provision, the imperatives for urban liveability represented an opportunity for meaningful change. A 2006 study showed Auckland's population of severely 
housing-deprived ${ }^{2}$ people numbered 9800 (Amore et al. 2006). An estimated $14 \%$ of Aucklanders live in fuel poverty, due to poor quality, uninsulated housing, and increases in the real price of electricity (Howden-Chapman et al., 2012).

Beyond the Auckland Plan, there is limited translation of liveability into everyday practices and processes for delivering public services. Investments in public spaces, cycling infrastructure, and waste minimisation programmes have been successful, however the lack of an over-arching framework to support liveability allows unsustainable modes of urban development to continue, particularly motorway expansion and damage to the natural environment (Salmon, 2016).

Figure 2: Auckland's Vision, Auckland Council, 2012,

\begin{tabular}{|c|c|c|c|c|c|}
\hline \multicolumn{2}{|c|}{ AUCKLAND'S VISION } \\
\hline
\end{tabular}

Furthermore, the commendable ambitions of the Auckland Plan do not realistically account for the limited authority of the Auckland Plan to influence existing forms of transport and infrastructure planning, and delivery of social services (Imran \& Pearce, 2015a). Fig. 2 shows the hierarchy of goals, outcomes and transformational shifts set out in the Auckland Plan.

In particular, the Auckland Plan's proposed shift to outstanding public transport within one network is limited within the current framework of transport investment in New Zealand which has strong and long-standing biases toward private vehicle travel (Hickman et al., 2014, Imran \& Pearce, 2015b. Mees \& Dodson, 2007). Auckland's public transport network has improved dramatically across the past decade, and central government grants for urban cycleways and rail infrastructure have generated good improvements in providing safer, sustainable travel choices. Between 20062015, annual transit patronage increased from 43 million to 60 million bus trips per year, 5.6 million to 15.4 million rail trips, and 4.2 million to 5.7 million ferry trips (Auckland Transport, 2015). However over the same period, the vehicle ownership rate has increased from 680 to 700 vehicles per thousand residents (Statistics New Zealand, 2013).

\footnotetext{
${ }^{2}$ Severe housing deprivation refers to having no accommodation, non-private accommodation, or being temporarily resident in a severely crowded private dwelling
} 
Achieving the vision of the Auckland Plan requires a substantial mode shift to public transport, walking and cycling to support projected population growth.

Auckland's attempt to operationalise liveability into land use planning and infrastructure provision illustrates the influence of urban policy agendas, and the distinctly post-suburban nature of the city's growth and development. Conflict between economic competitiveness and liveability reflect the divergent interventions across multiples levels of governance and influence of non-landed interests to shape outcomes of urban development.

\subsection{Transforming the drivers of change}

Auckland's governance reforms included new mechanisms to drive change in the city's development. Strategic spatial planning was adopted to support Auckland's growth and liveability. Strategic spatial planning produces a long term vision, actions to reach that vision, and identifies the means for implementation, emphasising transformative change and integrated planning (Albrechts, 2006 McFarlane et al., 2015). Institutional reform enabled region-wide co-ordination and planning of public infrastructure investments, however the politics of infrastructure in Auckland reflect inconsistent interventions across state actors and 330 the politicisation of the side effects of second modernity (Young \& Keil, 2010).

\subsubsection{Strategic spatial planning and the Auckland Plan}

The Auckland Plan's implications for spatial planning and budgetary allocations were operationalised through the Unitary Plan and Long Term Plan, respectively. Underpinning the Unitary Plan, Auckland's population growth projections anticipated an increase of 700,0001,000,000 new residents over 30 years (?). The Unitary Plan set out to accommodate this growth using the compact city approach. Proposed zoning for targeted intensification across a number of suburban centres and along transit corridors, with improved transit services to support better accessibility and reduce automobile dependence. The

340 Unitary Plan has been the locus of ongoing political and public debate across different stages of development. The draft Unitary Plan was published in March 2013, followed by the Proposed Auckland Unitary Plan (PAUP) in September 2013. A streamlined process for consultation involved an Independent Hearings Panel set up by the central government, hearing submissions from the public, business interests, civil society and community groups, as well as government departments.

Despite apparent support for intensified development during initial public consultations, extensive media coverage of the potential harms of intensified development spurred strong resistance in many suburban areas, as well as the 350 central government (Ministry for the Environment, 2013; Salmon, 2016). Heated debates on whether Auckland should grow up versus out reflected a characteristic post-suburban tension between the preservation of the existing suburban environment and the accommodation of new growth (Phelps et al., 2010).

The PAUP received over 13,200 submissions, and the notified plan was re355 leased to the public in August 2016. The Independent Hearings Panel recommended to increase zoning to allow for an additional 400,000 dwellings: $64 \%$ 
within the existing urban area, $33 \%$ in new urban areas, and $3 \%$ in rural areas. The plan adopted by Auckland Council in August 2016 largely accepted the recommendations of the Independent Hearings Panel. Notable changes from the PAUP included the removal of the retained affordable housing provisions, in favour of a mandatory affordability requirement for future zoning changes, and a bonus-based mechanism for land developed under existing zoning rules. Zoning for intensification was concentrated predominantly outside Auckland's isthmus, protecting the interests of existing residents in many inner suburbs.

The politics of post-suburban development depart from the traditional models for urban politics, which are dominated by landed interests. As suburban areas evolve into employment centres, a broader range of political interests emerge and land is valued for its long-term use value alongside the potential for financial gain Phelps2006,Phelps2011. While the outcomes of Auckland's Unitary Plan appear to support the urban growth machine theory of landed interests dominating urban politics, the politics around the Unitary Plan's process and public debates suggest a shift toward post-suburban politics. The interests of business and civil society groups show how the shifting use value of post-suburban land, climate change risks and traffic congestion (side effects of second modernity 375 (Beck, 1992), are politicised.

For example, Auckland's Chamber of Commerce advocated for accelerated release of business land to enable future expansion. This shows potential competition between residential and business land in suburban areas, as both look to expand supply in an effort to maintain competitive or affordable prices for firms and households respectively. Civil society groups were also active in the Unitary Plan process, providing a counter narrative to the media, business groups and anti-growth residential interests. Alternative visions were shaped by progressive urban planning approaches and explicitly targeted global imperatives for climate change mitigation and sustainable development. Climate change 385 advocacy group, Generation Zero, garnered considerable public support and effectiveness in facilitating public submissions on the Unitary Plan. Countering the arguments of landed interests, these advocates provided a strong influence through local media, also participating in public forums and debates.

\subsubsection{Infrastructure politics}

The politics of infrastructure frequently come to the fore in post-suburban development, and for Auckland transport infrastructure decision-making was strongly contested across local and central government actors (Young \& Keil, 2014). Auckland's new governance structure rescaled institutional arrangements for infrastructure delivery. Creation of council-controlled organisations for the 395 delivery of transport, water and wastewater infrastructure avoided unnecessary duplication across different providers and improved the co-ordination of planning across the metropolitan area. As discussed in the previous section, transport in Auckland is dominated by private vehicle travel despite relative improvements in public transport patronage over the past decade. There is es-

400 tablished institutional lock-in to the "predict and provide" model for private vehicle travel, although comparison of local and national transport policies sug- 
gests this is more dominant for national transport agencies (Hickman et al. 2014 Imran \& Pearce, 2015b; Mees \& Dodson, 2007).

A key element of the Auckland Plan's proposed transport investment is the City Rail Link (CRL), an underground rail tunnel extending the existing network in the city centre, creating a loop and doubling the peak-hour capacity of the existing rail network. The $3.4 \mathrm{~km}$ link had been proposed, in various forms, for over 100 years, delayed many times due a lack of funding or political will (Edgar, 2012, Newns et al., 2015). In the current regulatory context,

410 funding raised locally was not sufficient to pay for the estimated NZ $\$ 2.5$ billion (US $\$ 1.8$ billion) cost $t^{3}$. Auckland Council unsuccessfully petitioned the central government to share the cost of the CRL in 2010. The central government initially disputed the proposed benefits of economic agglomeration set out in the project's business case (Joyce, 2010). Ongoing campaigning for the project eventually led to a conditional funding commitment in 2013. The central government agreed to provide a $50 \%$ share of funding to begin construction in 2020 . The option to start construction earlier was conditional on targets set for increased rail patronage and employment growth in the city centre. In January 2016, the central government announced their decision to bring forward funding 420 assistance for the NZ $\$ 2.5$ billion project to begin in 2018 , to provide certainty for investors with large developments planned along the CRL route (Ministry of Transport, 2015). The flexibility of the central government's rationale for allocating funding to the CRL shows the inconsistency in state interventions and shifting justifications for major public investments. Within Auckland, this 425 is contributing to the variegated nature of the city's urban form. Fig. 3 illustrates the divergent transport planning approaches shaping Auckland's spatial development. Extensive motorway expansion in some areas contrasts with new cycling infrastructure, shared spaces and safer pedestrian environments in others. Integrated planning across transport modes is essential to ensure that the benefits of local public transport, walking and cycling infrastructure are distributed across all areas of the city.

\subsubsection{Rescaling across the local and central state}

The creation of Auckland Council also shifted the balance of power within New Zealand's national political economy. Auckland Council's constituents rep435 resent a substantial proportion of the national voter base, and Auckland's local issues are liable to shift to the national political agenda, potentially to the disadvantage of smaller cities and rural areas. The Royal Commission highlighted the importance of Auckland working collaboratively with central government (P.Salmon et al., 2009). Recommendations for a Cabinet Committee and Minister for Auckland within central government, to improve inter-agency integration,

\footnotetext{
${ }^{3}$ Auckland's transport is funded through a combination of property rates, user fees and regulatory charges, and contributions from the National Land Transport Fund. The National Land Transport Fund is collected centrally, primarily from petrol excise duty and road user charges
} 


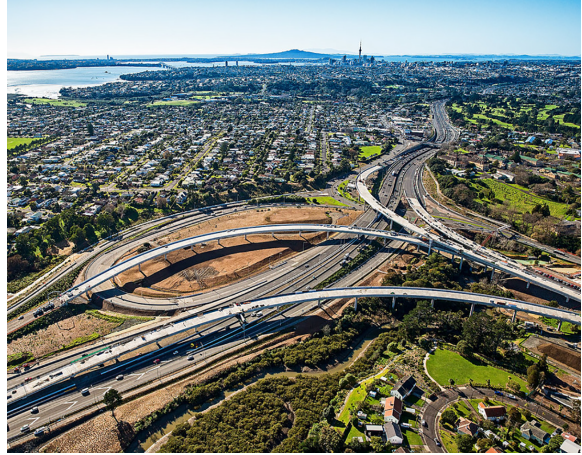

(a) Great North Road Interchange Image: New Zealand Transport Agency

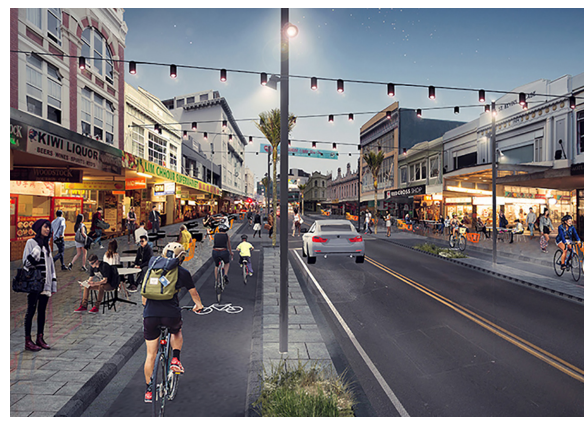

(c) Karangahape Road cycleway (proposed). Image: Auckland Transport

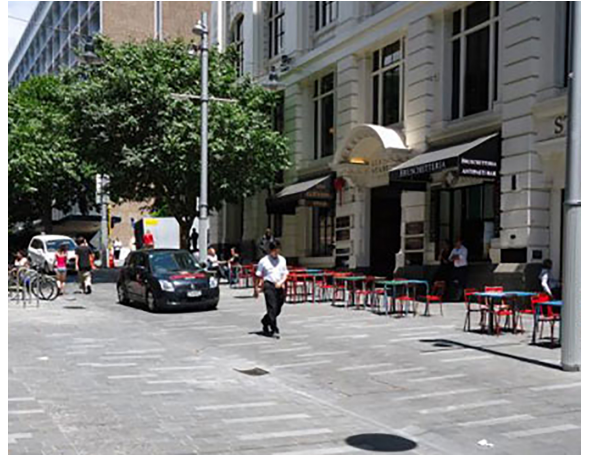

(b) Shared space, Elliott Street Image: Boffa Miskell

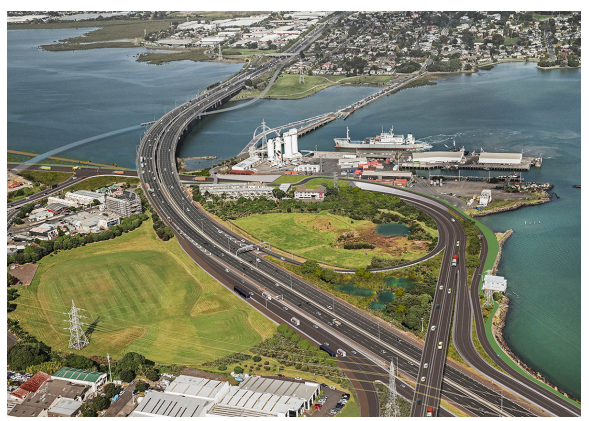

(d) Neilson Street Interchange (proposed) Image: New Zealand Transport Agency

Figure 3: Contrasting transport planning approaches across Auckland

were not adopted in the 2010 reforms (McFarlane et al. 2015).

Discord between Auckland's local governance and the National-led central government was notably contentious for housing and urban planning policies, centred on the need to support future growth, with sharply increasing property prices in Auckland's residential market. Between 2012 and 2016 the average house price in Auckland increased from NZ $\$ 562,000$ to NZ $\$ 956,000$ (REINZ, 2016). The state's response to this market shift characterises the influence the local and central state actors in post-suburbia and the in-between-ness of postsuburban development. Intervention by the central government in the housing 450 market between 20132016 reflected the uncertain roles across governing institutions.

Auckland Council's first strategic spatial plan envisaged a compact city, with targeted intensification and redevelopment across the city's centre and subcentres. In light of the rapidly-rising property values in Auckland, the central government was not fully supporting of this approach. The central government response was informed by a housing affordability metric which assumes a trade- 
off between housing affordability and planning restrictions (Murphy, 2014, Qian, 2010). Additional evidence suggests that an asset bubble may also have contributed to price increases, indicated by disproportionate growth of property values relative to rents (Greenaway-McGrevy \& Phillips, 2015). The central government primarily adopted supply-side measures to reduce the rate of house price increases, although interventions by the Reserve Bank of New Zealand went some way to address demand-side factors and limit macro-economic risks (RBNZ, 2015). The Special Housing Areas Act and Auckland Housing Ac-

465 cord (AHA) were introduced to facilitate an increased supply of dwellings, on the basis that Auckland's local planning rules were too stringent and the chief cause of rising property values (Productivity Commission, 2012). These mechanisms enabled more permissive regulations to grant resource consents, and designated tranches of land within and outside the existing city limits to increase land supply. Development in Special Housing Areas (SHAs) was required to meet affordability provisions for a certain share of new dwellings. While the AHA and SHAs were promoted as collaborative efforts across central and local government, public criticism of Auckland's planning policies by central government reveal conflicting values and political interests (Murphy, 2016). To

475 April 2016, the Auckland Housing Accord has delivered approximately 30,400 dwelling consents although only 1000 houses have been constructed (Auckland Council, 2016a). Conditions for affordability in SHAs are determined by median house prices: with either $10 \%$ of dwellings less than $75 \%$ of the median house price, or $5 \%$ of dwellings at a price that can be purchased on a median household income, given current mortgage rates and deposit requirements Auckland Council, 2014). Given the rapid rate at which property values are increasing, the effectiveness of affordability targets linked to the median price is limited. The supply-side approach taken to address Auckland's housing has been slow to tangibly increase the housing supply, or mitigate the growth of a housing market bubble.

\section{Scaling in the post-suburban polity}

Auckland's amalgamated governance model had profound implications for the city's spatial development. The scaling of governance relates to a dynamic process where the allocation of authority, decision making powers and accountability are subject to continuous change, being renegotiated, challenged and reformed by actors and institutions both within and external to a city (MacLeod \& Goodwin, 1999). Amalgamation provided the platform for a new policy agenda, orienting planning and investment around the goal of becoming the world's most liveable city. Governance reform also shifted the drivers of change

495 and their scale of influence: delivery of core infrastructure services by dedicated CCOs re-oriented planning and investment around strategic regional issues, and the unitary council developed a long term, strategic spatial plan to co-ordinate growth. Auckland's amalgamation also impacted New Zealand's national political economy. Auckland's dominance as a population and economic centre blurs the distinction between local and national issues is unclear and in several 
cases, leading to greater central government influence in local matters (Murphy, 2016). The ongoing re-allocation of responsibilities and decision-making powers between Auckland Council and the central government since 2010 reflect the continuous, incremental nature of rescaling in New Zealand.

Auckland's politics show the interplay between rescaling and the post-suburban nature of development. Prior to amalgamation, Auckland's fragmented governance structure led to political gridlock in planning for future growth and coordinating the required infrastructure investments . While a regional authority existed prior to 2010, its responsibilities and functions for spatial planning and 510 infrastructure provision were re-allocated to local authorities or corporatised entities, effectively hollowing out the institution (Memon et al., 2007). Amalgamation to create a unitary council shifted authority and legitimacy back to a region-wide entity, in an attempt to overcome the tension between accommodating growth and preserving the amenity of the existing environment. A single authority responsible for accommodating growth through strategic spatial planning and infrastructure investment internalised the burden of future growth where it was formerly externalised by the city's seven city and district councils. However scaling up other complex processes, particularly public consultation and consensus-building has proven to be challenging.

Intervention from the central government was catalysed by the housing market conditions, with the introduction of mechanisms such as the Auckland Housing Accord and Special Housing Areas to increase the city's housing supply. A new national policy on urban development capacity will ensure that the central government have an ongoing role in governing urban growth. The draft Policy

525 Statement issued in 2016 suggested that local authorities in high-growth areas can maintain an over-supply of developable land, based on population projections and housing and business land assessments (Ministry for the Environment 2016).

\section{Conclusions}

An earlier city profile in 1989 questioned whether Auckland would decide whether to strive for international status using the catch cry of market led efficiency, or shift the focus to emerging social inequalities and deprivation (Chalmers \& Hall, 1989). 27 years later, Auckland's amalgamation and goals for improved liveability show that the imperative for international significance is now undisputed. However the shifting urban agenda and rhetoric implies that this no longer rests solely on market performance but also on quality of life, despite potentially limitations in the concept of "liveability". Auckland exemplifies how global liveability rankings and quality of life surveys have introduced new outcomes to the domain of what is governable (Rydin, 2007), with signifi-

540 cant impacts on the governance arrangements and development of urban policy in cities worldwide (Bunnell, 2015). Critical reflection suggests that Auckland may need to adopt a more inclusive form of liveability, and translate this into local service provision to make a meaningful difference for the city's residents. Existing evidence shows that everyday life is unliveable for growing numbers of 
${ }_{545}$ Aucklanders and improving this will be an important test for the city's governance.

Post-suburban development presents a challenge to the city centre, with greater economic gravity in suburban areas. Auckland's city centre has grown dramatically over the past two decades, however it remains dwarfed by the re550 mainder of the city, with a $16 \%$ share of employment (Statistics New Zealand, 2013). Auckland's amalgamation in 2010, and the subsequent scaling of governance across local and central government, illustrate the challenges of postsuburban growth and interdependence between urban politics, spatial planning and infrastructure provision. Following major reform, some fine-tuning and in555 stitutional learning in Auckland's governance is to be expected, as organisations test new planning strategies, and adapt to unanticipated circumstances brought on by housing market volatility. The contingent and shifting balance of power across local and central state actors has shaped Auckland's post-suburban politics. Uncoordinated intervention and retreat in housing and transport policy limited the authority and legitimacy of Auckland's new local governance to take major decisions. However at key moments, power has been ceded to Auckland Council, such as the approval of the City Rail Link. Unfortunately, interventions over the course of the Unitary Plan's development have created greater peripheral expansion in Auckland, and limited intensification in existing sub565 urbs that are served by transit networks and significantly closer to employment centres and community services. The politics of infrastructure may be further exacerbated by planned expansion of Auckland's boundaries and substantial transport investment required to serve new suburbs.

The broader range of interests involved in urban politics signal a shift in Auckland's development. Civil society groups, leveraging the internet and social media to disseminate information and advocate for change. These actors have effectively introduced counter-narratives and promoted urban development that addresses the side effects of second modernity, targeting climate change and sustainable urban development. Poor voter turnout in the 2013 and 2016 elections 575 show there is continued need to improve public engagement and understanding of what is at stake in Auckland's development.

The state of Auckland's housing market may continue to be the dominant driver of urban politics. There is growing risk of a market correction in house prices, which would impact household wealth, local government revenues and the fiscal stability of New Zealand's economy. Despite the city's challenges, Auckland Council has maintained stability to prevent secession from the new jurisdiction and ongoing cooperation with the central government will help reach a balanced allocation of decision-making and responsibility across governance scales. 


\section{References}

Albrechts, L. (2006). Shifts in strategic spatial planning? Some evidence 口 from Europe and Australia. Environment and Planning A, 28. doi 10.1068/ a37304.

590 Amore, K., Viggers, H., Baker, M., \& Howden-Chapman, P. (2006). Severe n housing deprivation: The problem and its measurement. URL: http://www.

ntatisphere.govt.nz/ /media/Statistics/about-us/statisphere/ Files/severe-housing-deprivation/severe-housing-deprivation.pdf (Accessed 18 July 2016).

${ }_{595}$ Auckland Council (2012). Auckland Plan. URL: http://www. theaucklandplan.govt.nz/ (Accessed 5 February 2016).

Auckland Council (2014). Auckland Housing Accord: What's q been achieved in the first year. URL: https://www. beehive.

govt.nz/sites/all/files/Auckland-Housing-Accord-What\%E2\%80\% 99s-been-achieved-in-the-first-year.pdf (Accessed 27 July 2016).

Auckland Council (2016a). Auckland Housing Accord: Second quarterly re-

a port for third accord year. URL: http://knowledgeauckland.org.nz/ publication/show/1202/?mergedTopics=40. (Accessed 2 August 2016).

Auckland Council (2016b). Auckland retains third Mer-
${ }_{605}$ cer Quality of Living spot.

aucklandcouncil.govt.nz/articles/news/2016/02/
auckland-retains-third-mercer-quality-of-living-spot/ (Accessed
22 July 2016).

Auckland Transport (2015). AT Metro patronage report. 610 URL: https://at.govt.nz/about-us/reports-publications/ at-metro-patronage-report/ (Accessed 12 August 2016).

Beck, U. (1992). Risk Society: Towards a New Modernity. London, United Kingdom: Sage.

Bloomfield, G. T. (1967). The growth of Auckland 1840-1988. In J. Whitelaw 615 (Ed.), Auckland in Ferment (pp. 1-21). Auckland, New Zealand: New Zealand Geographical Society.

Bloomfield, G. T. (1973). The Evolution of Local Government Areas in Metropolitan Auckland, 1840-1971. Auckland, New Zealand: Auckland University Press.

${ }_{620}$ Boudreau, J.-A., Hamel, P., Jouve, B., \& Keil, R. (2006). Comparing metropolitan governance: The cases of Montreal and Toronto. Progress in Planning, $66,7-59$. doi $10.1016 / \mathrm{j}$.progress.2006.07.005. 
Brenner, N. (2011). Urban governance and the nationalization of state space: Political geographies of spatial keynesianism. In New State Spaces: Urban Governance and the Rescaling of Statehood. Oxford, United Kingdom: Oxford University Press.

Bruce, G. (2014). Our New Society. New Zealand Geographic, 126. URL: https: //www.nzgeo.com/stories/our-new-society. Accessed 22 July 2016.

Bunnell, T. (2015). Antecedent cities and inter-referencing effects: Learning from and extending beyond critiques of neoliberalisation. Urban Studies, 52, 1983-2000. doi $10.1177 / 0042098013505882$

Bush, G. (1972). Decently and in Order: The Government of the City of Auckland, 1840-1971. Auckland, New Zealand: Collins.

Bush, G. (1990). The historic reorganisation of local government. In M. Holland, \& J. Boston (Eds.), The Fourth Labour Government: Politics and Policy in New Zealand chapter 12. (pp. 232-250). Oxford, United Kingdom: Oxford University Press.

Chalmers, L., \& Hall, B. (1989). City profile: Auckland. Cities, 6, 82-90. doi:10.1016/0264-2751(89)90062-0.

${ }_{640}$ Chen, M. (2014). Transforming Auckland: The Creation of Auckland Council. Wellington, New Zealand: LexisNexis NZ.

Cheyne, C. (2015). Changing urban governance in new zealand: Public participation and democratic legitimacy in local authority planning and decision

naking 1989-2014. Urban Policy and Research, 33, 416-432. doi 10.1080/ 08111146.2014 .994740

Cox, K. R., \& Jonas, A. E. G. (1993). Urban development, collective consumption and the politics of metropolitan fragmentation. Political Geography, 12, 8-37. doi 10.1016/0962-6298(93)90022-Y.

Edgar, J. (2012). Urban Legend: Sir Dove-Myer Robinson. Auckland, New Zealand: Hachette.

Fitzmaurice, J. (2009). History of Auckland Wastewater and Mangere Wastewater Treatment Plant. In 3rd Australasian Engineering Heritage Conference.

Gagné, N. (2016). The Waxing and Waning of the Politics of Authenticity: The Situation of Urban-Based Māori through the Lens of Municipal Politics. City ES Society, 28, 48-73. doi:10.1111/ciso.12073.

Greenaway-McGrevy, R., \& Phillips, P. (2015). Hot property in New Zealand: Empirical evidence of housing bubbles in the metropolitan centres.

口 New Zealand Economic Papers, 50, 88-113. doi 10.1080/00779954.2015. 1065903 
Gupta, J., Pfeffer, K., Ros-Tonen, M., \& Verrest, H. (2015). Setting the scene: The Geographies of Urban Governance. In J. Gupta, K. Pfeffer, H. Verrest, \& M. Ros-Tonen (Eds.), Geographies of Urban Governance (pp. 3-26). Cham, Switzerland: Springer. (1st ed.).

Harris, C. (2005). Slow train coming: the New Zealand state changes its mind about Auckland transit, 1949-56. Urban Policy and Research, 23, 37-55. doi:10.1080/0811114052000341946.

Hayward, J. (2011). Mandatory Māori Wards in Local government: Active Crown protection of Māori Treaty Rights. Political Science, 63, 186-204. doi:10.1177/0032318711423908.

Hickman, R., Austin, P., \& Banister, D. (2014). Hyperautomobility and governmentality in Auckland. Journal of Environmental Policy and Planning, 16, 419-435. doi:10.1080/1523908X.2014.954074

Horton, S. (1995). Change and continuity: Urban policy in New Zealand. Urban Policy and Research, 13, 37-47. doi:10.1080/08111149508551670.

675 Howden-Chapman, P., Viggers, H., Chapman, R., O’Sullivan, K., Telfar Barnard, L., \& Lloyd, B. (2012). Tackling cold housing and fuel poverty in New Zealand: A review of policies, research, and health impacts. Energy Policy, 49, 134-142. doi:10.1016/j.enpol.2011.09.044.

Imran, M., \& Pearce, J. (2015a). Auckland's first spatial plan: Ambitious

aspirations or furthering the status quo? Cities, 45, 18-28. doi:10.1016/j. cities.2015.02.005.

Imran, M., \& Pearce, J. (2015b). Discursive barriers to sustainable transport in n. New Zealand cities. Urban Policy and Research, 33, 392-415. doi 10.1080/ 08111146.2014 .980400 .

Johnson, H., \& Moloughney, B. (2007). Asia in the Making of New Zealand. Auckland, New Zealand: Auckland University Press.

Joyce, S. (2010). Roading and Public Transport Projects, Auckland - Benefitcost Ratios. New Zealand Parliamentary Debates, 66915817.

Keil, R. (2000). Governance restructuring in Los Angeles and Toronto: Amalgamation or secession? International Journal of Urban and Regional Research, 24, 758-781. doi:10.1111/1468-2427.00277.

Kennedy, C., Miller, E., Shalaby, A., Maclean, H., \& Coleman, J. (2005). The four pillars of sustainable urban transportation. Transport Reviews, 25, 393414. doi: $10.2148 /$ benv.42.1.120.

695 La Roche, J. (Ed.) (2011). Evolving Auckland: The City's Engineering Heritage. Christchurch, New Zealand: Wily Publications. 
Lewis, N., \& Murphy, L. (2015). Anchor organisations in Auckland: Rolling n constructively with neoliberalism? Local Economy, 30, 98-118. doi 10.1177/ 0269094214563915 .

Local Government New Zealand (2016). Final voter turnout 2016. URL: "http://www.lgnz.co.nz/vote2016/final-voter-turnout-2016/" (Date last accessed 29-December-2016).

MacLeod, G., \& Goodwin, M. (1999). Space, scale and state strategy: Rethinking urban and regional governance. Progress in Human Geography, 23, 503-527. doi:10.1191/030913299669861026

McFarlane, K., Solomon, R., \& Memon, A. (2015). Designing institutions for strategic spatial planning: Auckland's governance reforms. Urban Policy and Research, 33, 452-471. doi:10.1080/08111146.2015.1061988.

Mees, P., \& Dodson, J. (2007). Backtracking Auckland?: Technical and communicative reason in metropolitan transport planning. International Planning Studies, 12, 35-53. doi $10.1080 / 13563470701346568$.

Memon, A. (2008). Role more than roads, rubbish and rates. URL: http:// www.nzherald.co.nz/nz/news/article.cfm?c_id=1\&objectid=10547280 (Date last accessed 12-July-2016).

715 Memon, A., Davies, T., \& Fookes, T. (2007). Institutional arrangements for metropolitan government and strategic planning in Auckland. New Zealand Geographer, 63, 43-54. doi $10.1111 / \mathrm{j} .1745-7939.2007 .00089 . \mathrm{x}$.

Ministry for Local Government (2009). Making Auckland Greater. Technical Report Ministry for Local Government, New Zealand Government.

${ }_{720}$ Ministry for the Environment (2010). Building competitive cities: Reform of the urban and infrastructure planning system. A discus-

sion document. URL: http://www.mfe.govt.nz/publications/rma/ building-competitive-cities-discussion-document (Accessed $14 \mathrm{Au}-$ gust 2016).

725 Ministry for the Environment (2013). Government submission on the pron posed Auckland Unitary Plan. URL: http://www.aucklandcity.govt.nz/ UPSubs/UPASEP000318.pdf (Accessed 29 December2016).

Ministry for the Environment (2016). Proposed National Policy Statement on Urban Development Capac-

730 ity. URL: http://www.mfe.govt.nz/more/towns-and-cities/ proposed-national-policy-statement-urban-development-capacity (Accessed 29 December 2016).

Ministry of Transport (2015). City Rail Link: Proposal to make early financial commitment. Treasury/MoT Report Ministry of Transport, New Zealand Government. 
Mitchell, D., Enemark, S., \& van der Molen, P. (2015). Climate resilient urban development: Why responsible land governance is important. Land Use Policy, 48, 190-198. doi:10.1016/j.landusepol.2015.05.026.

Modarres, A., \& Kirby, A. (2010). The suburban question: Notes for a research program. Cities, 27, 114-121. doi 10.1016/j.cities.2009.11.009.

Murphy, L. (2014). 'Housing, we've got a problem': The political construction of a housing affordability metric in New Zealand. Housing Studies, 29, 893-909. doi $10.1080 / 02673037.2014 .915291$.

Murphy, L. (2016). The politics of land supply and affordable housing: Auckland's Housing Accord and Special Housing Areas. Urban Studies, 53, 15302547. doi $10.1177 / 0042098015594574$

Newns, B., Hawkins, S., \& Ireland, T. (2015). Auckland City Rail Link: the first 100 years. In Proceedings - Rapid Excavation and Tunnelling Conference (pp. 868-880).

Phelps, N. (2010). Suburbs for nations? some interdisciplinary connections on n the suburban economy. Cities, 27, 68-76. doi:10.1016/j.cities.2009.11. 005 .

Phelps, N. (2015). Sequel to Suburbia. Cambridge, MA: MIT Press.

Phelps, N. A., Wood, A. M., \& Valler, D. C. (2010). A postsuburban world? an outline of a research agenda. Environment and Planning A, 42, 366-383. doi:10.1068/a427.

Porter, M. E. (1995). The competitive advantage of the inner

q city. Harvard Business Review, 73. URL: https://hbr.org/1995/05/ the-competitive-advantage-of-the-inner-city. (Accessed 14 August 2016).

Pownall, L. L. (2008). Metropolitan Auckland 1740-1945: The historical geography of a New Zealand city. New Zealand Geographer, 6, 107-124. doi: $10.1111 / j .1745-7939.1950 . t b 01716 . x$.

Productivity Commission (2012). Housing affordability inquiry. Technical Report New Zealand Productivity Commission.

Qian, Z. (2010). Without zoning: Urban development and land use controls in Houston. Cities, 27, 31-41. doi 10.1016/j.cities.2009.11.006.

RBNZ (2015). Financial Stability Report. Technical Report Reserve Bank of New Zealand.

770 REINZ (2016). Median house price - REINZ. URL: https://www. interest.co.nz/charts/real-estate/median-price-reinz (Accessed 11 August 2016). 
Royal Commission on Auckland Governance (2009). History of Auckland's governance. (pp. 111-133). Royal Commission on Auckland Governance.

775 Rydin, Y. (2007). Indicators as governmental technology? The lessons of community-based sustainability indicator projects. Environment and Planning D: Society and space, 25, 601-624. doi $10.1068 / \mathrm{d} 72 \mathrm{j}$.

Ryks, J., Pearson, A., \& Waa, A. (2016). Mapping urban Māori: A populationbased study of Māori heterogeneity. New Zealand Geographer, 72, 28-40. doi: $10.1111 / \mathrm{nzg} .12113$

Salmon, G. (2016). Auckland. In L. Early, P. Howden-Chapman, \& M. Russell (Eds.), Drivers of Urban Change (pp. 19-60). Wellington, New Zealand: Steele Roberts.

Salmon, P., Bazley, M., \& Shand, D. (2009). Royal Commission on Auckland Governance. Report Royal Commission.

Sassen, S. (2005). The Global City: Introducing a Concept. Brown Journal of World Affairs, XI, 27-43.

Statistics New Zealand (2013). New Zealand Census. URL: http:// http://www.stats.govt.nz/census/2013-census.aspx (Accessed $15 \mathrm{Au}$ gust 2016).

Statistics New Zealand (2015a). Regional Gross Domestic Prodq uct: Year ended March 2014. URL: http://www.stats.govt.

nz/browse_for_stats/economic_indicators/NationalAccounts/ regional-gdp-info-releases.aspx (Accessed 14 August 2016).

795 Statistics New Zealand (2015b). Subnational Population Estimates. URL: http:

//www.stats.govt.nz/browse_for_stats/population/estimates_and_ projections/subnational-population-estimates-info-releases.aspx (Accessed 14 August 2016).

Teaford, J. (2011). Suburbia and post-suburbia: A brief history. In N. Phelps, ${ }_{800} \& \mathrm{~F} . \mathrm{Wu}$ (Eds.), International Perspectives on Suburbanization. Palgrave Macmillan.

Thomas, K. (2014). New Zealand councils: local government beyond

口 politics. URL: http://www.theguardian.com/public-leaders-network/ 2014/jun/05/new-zealand-councils-beyond-politics (Accessed 12th 805 August 2016).

Tizard, J. (2002). AREDS crucial to Auckland and NZ's future. URL: https:

1/Www.beehive.govt.nz/release/areds-crucial-auckland-and-nz\%E2\% 80\%99s-future (Accessed 5th August 2016). 
Wetzstein, S. (2008). Relaunching Regional Economic-Development Policy and Planning for Auckland: Remaking the State and Contingent Governance under Neoliberalism. Environment and Planning C: Government and Policy, 26, 1093-1112. doi:10.1068/c0748r.

World Bank (2015). Competitive Cities for Jobs and

Growth: What, Who, and How. URL: http://

documents.worldbank.org/curated/en/902411467990995484/pdf/ 101546-REVISED-Competitive-Cities-for-Jobs-and-Growth.pdf $\quad$ Accessed 14 August 2016.

Wu, F., \& Phelps, N. A. (2011). (Post)suburban development and state entrepreneurialism in Beijing's outer suburbs. Environment and Planning A, 43, 410-430. doi $10.1068 / \mathrm{a} 43125$

Young, D., \& Keil, R. (2010). Reconnecting the disconnected: The politics

of infrastructure in the in-between city. Cities, 27, 87-95. doi $10.1111 / \mathrm{j}$. $1745-5871.2012 .00768 . x$

Young, D., \& Keil, R. (2014). Locating the Urban In-between: Tracking the Urban Politics of Infrastructure in Toronto. International Journal of Urban and Regional Research, 38, 1589-1608. doi 10.1111/1468-2427.12146.

Zöllner, E. (2004). Urban Policy in New Zealand - New Initiatives and Fa口 miliar Barriers. Urban Policy and Research, 22, 221-230. doi 10.1080/ 0811114042000229663. 